\title{
State Policing and National Security in Nigeria
}

\author{
Odeh Adiza Mercy \\ Department Of Political Science, Faculty of Social Sciences, University Of Jos, Jos, Nigeria \\ veemsm@yahoo.com \\ Umoh Nanji \\ Department Of Political Science, Faculty of Social Sciences, University Of Jos, Jos, Nigeria
}

\section{Doi:10.5901/mjss.2015.v6n1s1p412}

\begin{abstract}
Nigeria is battling its worst level of insecurity since the civil war which ended in 1970. The need to reform and reposition the Nigeria Police Force has been topical in debates to improve security in the country. In fact, several high-powered committees have been set up and dozens of reports churned out on this subject. These efforts have been geared towards developing a formidable police force that will perform its constitutional duties of maintaining law and order and securing the lives and properties of all Nigerians. However, results have shown that the efforts of government have not delivered the desired results. The objective of this study therefore was to highlight the urgency in the need to establish a state police that will be capable of tackling the current challenge of gross insecurity in Nigeria. The study relied on secondary data in evaluating the feasibility of state policing in Nigeria. The analysis centred on variables like the reorientation of the force, insufficient budgetary allocation and judicious use of security vote, the practice of true federalism, the creation of employment opportunities and so on, in drawing its conclusions. Findings revealed that the current centralised system of administering the police force may not be tenable in adequately curbing the menace of insecurity in Nigeria. Recommendations proffered include the need to decentralize the police force forthwith. It is expected that the adoption and implementation of this among other suggested strategies will boost the operative capacity of the Nigerian Police Force to effectively carry out its designated roles and bring the mounting insecurity in the country under control. It is hoped that the results from this study will encourage Nigerian policy makers in formulating the right policies for national security. Besides, the results from this study will be useful to other researchers and students of public policy.
\end{abstract}

Keywords: Insecurity, State-Policing, Intelligence-gathering, Effectiveness, Federalism, Decentralization

\section{Introduction}

The rising insecurity in Nigeria in recent times has called to question the centralisation of policing in the country and advanced the need to decentralise the force, to ensure that states establish, maintain and control their police formations. Antecedent to this was the idea of community policing, based on the notion of cooperation between police officers and private citizens in communities to grapple with crimes and sundry social vices. Central to the idea is the neighbourhood principle that presupposes that everyone in the vicinity knows each other, thereby making it easy to monitor deviants in the community. Historically, Nigeria used to be one of the relatively secure nations in the West African sub-region. Unfortunately, the nation has suddenly metamorphosed into an abode of serial bombings, hostage taking, kidnapping, armed robbery, cold-blooded murders and ethno-religious conflicts traceable to militant groups with conflicting political and religious ideological leanings.

Recently, political tensions are compounded by the reality that although the Nigerian economy has recorded some growth since 1999, this wealth has not been seen or felt by the majority of Nigerians. Nearly three-quarters of the populace live on less than one dollar a day in a country that has earned oil revenues (at least USD 280 billion) over three decades, including the past few years of high oil prices (Eme, 2009). Ethnic tensions, religious differences, limited economic opportunities, and numerous socio-political grievances are all fuelling the unrest in Nigeria and contributing to flashpoints of violence. Indeed many political analysts are of the opinion that Nigeria is fast degenerating into the Hobbesean state of nature where life is short, nasty and brutish and living has become an issue of survival of the fittest (Adebakin and Raimi 2012). Anarchy is closing in while law and order are losing their sting. Hoodlums, criminals and terrorists have virtually taken over the nation. According to Okechukwu and Anyadike (2013), most Nigerians now sleep with one eye open as those who are lucky to escape burglars are kept awake all night by booming sounds of gunshots or 
dins of bomb explosions by those too powerful to be stopped.

Some of these groups are the Niger-Delta militants, campus cults, armed robbers and kidnappers, O'odua People's Congress (OPC) Egbesu boys and most recently the Boko Haram insurgent group. The resultant effect has been the destruction of valuable government facilities, loss of lives and properties and an increase in budgetary appropriation and expenditure on security. This portends devastating consequences for sustainable economic development in the country. A study by Adebakin and Raimi (2012) indicated that Nigeria's expenditure on national security is rising faster than ever before. The Federal government has continued to appropriate huge funds for defence and internal security in the national budget; a trend that has denied sectors like the education, health, agriculture and infrastructural the needed attention and capital. Nigeria ranks 57th in the global rating, 7th in Africa and is regarded as the largest spender on military expenditure in the West African sub-region (Adebakin and Raimi 2012). In all these, the government has not addressed the fundamental immediate and remote causes of these manifestations. All that have dominated the government's security policy have been redeployment of police top brass and other security personnel without much attention to the issues of political/religious intolerance, high unemployment, escalating impoverishment and the population's despondency, etc. that have become unbearable to ordinary Nigerians.

Nigeria's military expenditure in 2009 was $\$ 1.864$ billion or N276.5 billion, representing 0.90 percent of the Gross Development Production (GDP). In the 2008, 2010, 2011 and 2012 fiscal years, the total expenditure earmarked for both internal security and defence in the approved budgets were N292.7 billion, N422.9billion, N563.2 billion and N 921.91 billion respectively (Central Bank of Nigeria, 2012). This is five times greater that the expenditure on security in Cote d'Ivoire and almost 15 times of that of Ghana (Oladesu, 2012). Apart from the expenditure on defence and internal security at the Federal level, the 36 states and 774 local government councils in Nigeria enjoy security votes, a fund that has come under severe scrutiny and criticism in recent times. Some public analysts including few serving governors have frowned at these security votes on the grounds that it is not economically viable in the face of the diverse challenges bedevilling the nation. Moreover, the security votes have encouraged monumental fraud and stealing of state fund by the political elites in Nigeria (Eboh and Obodoechina 2012).

Furthermore, Okechukwu and Anyadike (2013) asserted that in the face of these expenditures, the security forces appear helpless to curb the insecurity trends. The internal security mechanism appears to have broken down completely as the state no longer has the monopoly of the means of violence. In addition, the involvement of very powerful individuals has escalated the problem, bringing an unprecedented sophistication to the vice, as their automatic weapons such as the AK94 and mode of operation have beaten the low ranging arms of the police hollow in the crime war. At least, ten to thirty lives are lost either through violent robbery, political assassinations, murders and religious killings in the north eastern parts of Nigeria on a daily basis. Other manifestations of threats to national security include drug trafficking, human trafficking, human sacrifice, ritual killings, sectarian and political violence, communal strife and natural disasters (Darmer, 2004). Indeed, the realities on ground are very worrisome. Even when government officials are targets of the violent attacks and some of them are kidnapped by hungry the federal and state governments have been unable to surmount the challenges.

These evidences lend credence to the fact that the insecurity situation calls for a reform in the security sector, because of the sole responsibility of government to protect the lives and properties of citizens. A government that cannot guarantee this, to say the least, has lost its essence. Apart from militancy, economic corruption gives impetus to the threats to national security. National security is a big-time business, as bureaucrats and military officials are said to divert security votes and expenditure on defence to personal coffers. They tactically fuel the insecurity in different parts of the country to get more funding from all levels of government (Eboh and Obodoechina 2012). Albert (2005) described the incidences of bombing and attendant threats to national security in Nigeria, as a political intrigue unleashed on the nation by the ruling elites to cover up corruption. These justify the clamour for an effective and preventive state policing in Nigeria (Tunde-Awe, 2005). Antagonists against the establishment of State Police argue that the country is not ripe for it and that the state governors might turn them into a personal army to fight political oppositions in their states (Ehindero, 2012). To provide for an evidence-based policy in this regard, this study critically examines the suitability of a state police within the Nigerian federal structure. It also seeks to proffer some workable solutions to the current security challenges in the country.

\section{The Concept of National Security}

Security is critical to the survival of any nation to forestall lawlessness, chaos and the eventual disintegration of the system. Security is considered as a dynamic condition, which involves the relative ability of a state to counter threats to its core values and interests (Omede, 2011). According to McGrew (1988), the security of a nation is predicated on two 
central pillars viz; the maintenance and protection of the socio-economic order in the face of internal and external threat on one hand and the promotion of a preferred international order, which minimises the threat to core values and interests, as well as to the domestic order on the other hand. Similarly, Nwolise (2006) states that security is an all-encompassing holistic concept which implies that the territory must be secured by a network of armed forces; that the sovereignty of the state must be guaranteed by a democratic and patriotic government, protected by the military, police and the people themselves. The people must not only be secure from external attacks but also from devastating consequences of internal upheavals, unemployment, hunger, starvation, diseases, ignorance, homelessness, environmental degradation and pollution and socio-economic injustices. Krahmann E. (2003) on his part defined security as activities that ensure the protection of a country, persons, and properties of the community against future threats, danger, mishaps and all other forms of perils. Here security is viewed only as a futuristic phenomenon. In all places and countries, security is a multidimensional subject of numerous debates and is considered a 'first-order-value' worth preserving. There is no consensus about a general definition of security. However, two contending perspectives provide the basis for the conceptualization of national security: the realist/strategist theoretical framework predicated on the primacy and centrality of the state in conceptualizing security and the non-strategic definition that relies on socio-economic factors.

\subsection{Perspectives on the Concept of Security}

The two contending perspectives for the conceptualization of national security are:

i. The realist/strategist

ii. The non-strategic

\subsubsection{The Realist/Strategic Perspective:}

The strategic perspective conceptualizes national security as self defence by amassing arms to deter aggression. This perspective sees conflict between men and states as endemic. The international political system here is anarchic. Power and the struggle for power and control of resources are central to this manner of thinking. Here, states are constrained by pacts, audiences, treaties and tenets of international law that they see as being in their own interests. Security in this context concentrates on the military, military values, strategies and capabilities and the survival of the state. Invariably, since the survival of the state is based on security, it follows that security must have the highest ranking in the allocation of the state resources. The danger in this view is the tendency to equate national security with only the defence of the state as noted by Nweke (1988) who sees this resulting in bestowing undue responsibilities to the military as if the armed forces alone are the guardians of national security. This has been one of the subtle reasons for coup d'états in many parts of the world. Buzan (1991) argued that this strait-jacket militaristic approach to security that dominated the early discourse on security was simple-minded and subsequently led to the underdevelopment of the concept.

\subsubsection{The Non-Strategic Perspective:}

Since the end of the cold war, there have been attempts to shift the conceptualization of security from a state-centric perspective to a broader view that places premium on individuals (Buzan 1991). Here, human security embodies elements of national security, human rights and national development as major barometers. The concept of security is widened from the level of the states to societies and individuals and from military to non-military issues. Dyke (1966), asserts that national security embodies the sovereignty of the state, the inviolability of its territorial boundaries, and the right to individual and collective self-defence against internal and external threats. However, the state is secure only when the aggregate of people organized under it have a consciousness of belonging to a common sovereign political community; enjoy equal political freedom, human rights, economic opportunities, as well as when the state itself is able to ensure independence in its development and foreign policy. The non-strategic school of thought defines national security as not just military defence of territory but also internal stability, socio-economic development, protection of life, property and economic resources of the country by constituted authorities, using security bodies. McNamara (1968) aptly captures it thus;

"In a modernizing society, security means development. Security is not military force though it may involve it; security is not military hardware, though it may include it. Security is development and without development, there can be no security... the security of any nation lies not solely or even primarily in its military capacity; but equally in developing relatively stable patterns of economic and political growth". 
In consensus with the above, Adamu (1990) observed that security extends to the interlocking realms of economic self-reliance, cohesion, and political stability. Adebakin and Raimi (2012) argued that the concept of national security has always been associated with the safety and survival of the state and its citizens from harm or destruction or from dangerous threats. For Stan (2004), national security refers to the zeal to avoid, prevent, reduce, or resolve violent conflicts- whether the threat originates from other states, non-state actors or other socio-economic conditions. Furthermore, Babangida (2011), views national security as the physical protection and defence of the citizens and a nation's territorial integrity. It is also the promotion of the economic well being and prosperity of the citizens in a safe and secure environment that promotes the attainment of national interests and those of her foreign partners. Otto and Ukpere (2012) on their part asserted that "security means protection from hidden and hurtful disruptions in the patterns of daily life in homes, offices or communities; security must be related to the presence of peace, safety, happiness and the protection of human and physical resources or the absence of crisis, threats to human injury among others. Adebakin and Raimi (2012) identified seven (7) critical dimensions of national security which are:

a. Economic Security: It entails an assured basic income for individuals, which manifests as provision of productive employment opportunities and adequate remuneration. Unemployment, economic hopelessness and chronic poverty threaten economic security.

b. Food Security: It requires that all members of the community, at all times, have access to basic food and nutrition that ensures stable wellbeing and protection from hunger, starvation and malnutrition. Poor yield from farmlands; endemic famine/drought etc threaten food security.

c. Health Security: It requires an assurance of a minimum protection from all forms of diseases and unhealthy lifestyles that cut short human lives. Threats to health security are absence of clean water, dirty environment and poor hygiene/health education.

d. Environmental Security: It requires a planned protection of people from the short and long-term ravages of nature, spill-over negative effects of environmental degradation and abuse of the ecosystem as a result of desertification, gas flaring/emission, pollution of fresh water, careless use of industrial chemicals, etc.

e. Personal Security: It concentrates on the protection of lives and property from physical violence created by the state, external states, violent individuals and sub-state actors. It broadly conceptualises human security as that aspect of national security which refers to freedom from fear and freedom from want, safety from chronic threats such as hunger, disease, and repression as well as protection from sudden and harmful disruptions in the patterns of daily life, whether in homes, in jobs or in communities.

f. Community Security: It assures the protection of people from the loss of traditional homeland, customs and values from all types of sectarian and ethnic or religion-related conflicts.

g. Political Security: It pertains to the protection of fundamental human rights of the electorates as well as freedom from systematic torture, ill treatment and coercion. It broadly describes electoral rigging, vote buying and such frauds etc.

National security is a sacrosanct and non-negotiable phenomenon in human society and cannot be accorded a single definition. In his view, David (2006) posited that security in an objective sense, refers to the absence of threats to acquire values while in a subjective sense, it refers to the absence of fear that such values will be attacked. In spite of its conceptual complexities, security is evidently vital for national cohesion, peace and sustainable development

\section{A Case for State Policing in Nigeria}

The view of the state having monopoly over the means of legitimate violence led into the creation of specialized agencies like the police and the Armed Forces charged with the responsibility of controlling the use of violence by other groups. Currently the police in Nigeria are scheduled to perform the following duties:

i. Crime Prevention

ii. Protection of lives and properties

iii. Enforcing law

iv. Maintenance of peace and public order.

V. Providing a wide range of services to the citizens (Akuul 2011).

By doing this, it has the right to use coercive means in order to establish social control. The Nigeria Police is statutorily required to also fight crime through detection, investigation, apprehension and prosecution of offenders in law courts as well as the protection of lives and property through proactive policing. Tinubu (1993) asserted that the place of the police in Nigeria cannot be compromised. Their constitutional and statutory functions according to him are well defined so that the force can manage crisis situations and maintain peace and security. Specifically, this was crafted into 
Section 14(b) of the Nigerian Constitution (1999) which declared that the security and welfare of the people shall be the primary purpose of government. The Nigerian Police Force (NPF) according to Section 194 of the 1979 constitution is designated as the national police force with exclusive jurisdiction throughout the country (Egbosiuba, 2013). Section 215 of the 1999 constitution also states that before a state police commissioner carries out an order issued by his governor, he may "request that the matter be referred to the president or such minister of the government of the federation as may be authorised in that behalf by the president for his directions". The unfortunate outcome is that the police contingents in the various states are strictly under the operational control of the Inspector General. Therefore, if Nigeria is to contain the current trends of insecurity in the country, an informed constitutional approach and policy decision must be taken to revamp the security sector through target-oriented productive reforms.

Currently, there are community security groups in the states, even though they have not been officially designated as state police (James, 2014). In Kano State, it is called the Hisbah and was used by the state government to enforce the sharia legal system. There were once the Bakassi boys, which operated in Anambra and Abia States. In Borno State under Ali Modu Sheriff, there was the ECOMOG group, which many people believe has transformed into the Boko Haram sect, which is presently terrorising the country (James, 2014). The opponents of state police use some of the human rights abuses perpetrated by these groups as basis for their argument, saying that the groups operated contrary to the provisions of the Nigerian constitution. This school of thought also argues that the state police will be abused by the state governors. They opine that it will produce the same result as the immunity clause which has entrenched corruption at various levels of government.

The introduction of state police they argue will worsen the bad security situation in most states of the federation. That is, considering the fate of civil society groups, the community-based organizations, the media and public affairs commentators who are vulnerable in the hands of dare-devil politicians that are easily irritated by fair and objective criticism (James, 2014). Furthermore, Information Nigeria (2014) reported that the Inspector-General of Police (IGP), had reiterated his objection to the establishment of state police in Nigeria, arguing thus: "We are not yet ripe for the state police. I'm not saying there shouldn't be state police; we are not yet ripe for it. l'll cite several examples. Check countries of the world which are operating the state police, how many years from their independence? Take Britain, take United States, and take any European country that you can call as an instance, we are talking of 200 years in the United States. How old are we? Do they have the challenges we have?"

This is apart from the fear of governors using state police against political opponents. The opponents of state police further base their position on politicians who already use all manner of funny-looking guys as personal guards to terrorise the common man. In addition, they argue that state funds will be used to influence a handful of members of the security agencies to intimidate, harass, maim and in extreme cases, kill innocent citizens who perform their statutory duties (Egbosiuba, 2013). Some may resort to the use of security agents to force reporters to do their biddings. They argue on situations, where Governors can order certain uncompromising members of the House of Assembly around for voicing their dissenting views on an election. It will be better imagined than not, if such governors have powers over the police in the name of state police (Egbosiuba, 2013). The solution according to this view is that Nigerians should rise up to canvass for adequate funding, efficient monitoring of disbursement of funds for proper utilization and training of Nigerian Police force for optimal performance and service delivery, instead of subscribing to the provision of state police in the constitution.

However, Fashola (2014) stated that the call for state police is a subject of the wider clamour for "true federalism". Prominent lawyers in Nigeria have decried the over-centralization of the police, drawing out implications for public order and safety. Governors are the Chief Security Officers of their states with 'security votes', yet they have no control over the police. Rather, it is the Inspector General of Police (IGP) in Abuja through his Commissioners of Police (COPs) in each state that has the sole power over this monolith command structure (Eboh, 2014). The first republic had local, regional and central police institutions in accordance with the tenets of true federalism. Unfortunately, this arrangement was eroded by the military and replaced with the unitary system which the country's democratic order has adopted over the years. Ochei (2014) held that a veritable way out of the current security quagmire would be the establishment of state police formations. He views pundits' fear of abuse of the force by state governors as untenable in the light of the damning allegations of abuse of the Nigerian Police Force (NPF) by those who currently run and control it. Moreover, Eboh, (2014) insisted that the governors will never abuse the state police because the State Houses of Assembly will always be there to monitor their activities and ensure compliance. In view of these arguments, support for the notion of state policing can be further hinged on an analysis of the following indicators:

i. Re-orientation of the Force;

ii. Insufficiency of Budgetary Allocation;

iii. Judicious use of the security vote; 
iv. The Utilisation of policemen;

v. Decentralisation and the practice of true Federalism;

vi. Creation of employment opportunities;

vii. Effective intelligence gathering

\subsection{Re-orientation of the Force}

It is commonly said that doing the same thing over and over without change or innovations always produces the same results. The Nigerian police force is currently bugged with many problems and appears to be the proverbial leopard that cannot change its spots. It is not unusual to see policemen collecting bribes from privately owned public transport vehicles on major highways all over the country. In some cases, policemen delay transport companies on the highway for failure to give them bribe (Eboh, 2014). Some motorists and commuters have lost their lives for these reasons, to psychologically imbalanced, trigger-happy policemen. Also, a lot of these police officers are not adequately trained and are ill-equipped to fight crime. Some criminals are even more equipped than the police (Egbosiuba, 2013). The result is that many of them get killed in the line of duty. Others in 'reverence' of superior fire power allow criminals finish their operations before showing up at a crime scene, thereby leaving the populace vulnerable to the criminals. Instances abound in which states like Borno, Lagos, etc. have made diverse contributions in kind to the police formations within their jurisdictions. These have comprised vehicles to boost rapid response, communication gadgets, armoured personnel carriers, etc. to enhance the quality of policing. It is the proposition of this paper that if states are given the constitutional backing to handle their police affairs, the quality and by extension, the confidence of the policemen, even those on the streets, will be boosted.

\subsection{Insufficiency of Budgetary Allocation}

An analysis of Nigeria's defence allocation by Muazu, (2012) as a percentage of the national budget for five years (20082012) paints an unsavoury picture of underfunding as revealed in the table below:

Table 1: An analysis of Nigeria's defence allocation as a percentage of the national budget over a 5-year period

\begin{tabular}{|c|c|c|c|c|}
\hline 2008 & 2009 & 2010 & 2011 & 2012 \\
\hline $5.75 \%$ & $5.78 \%$ & $5.69 \%$ & $8.48 \%$ & $7.74 \%$ \\
\hline
\end{tabular}

(Source - Muazu, 2012)

The information above reveals that the Nigerian government's financial allocation to the security sector is insufficient. Comparatively, in the United States of America (USA), the 2012 total federal budget request was \$3.8Trillion, out of which the defence related expenditure for the fiscal year was estimated between \$1.0T - \$1.4T, representing $34.21 \%$ of the national budget, under the discretionary spending schedule (Muazu, 2012). Nigeria may as a result of its status, be unable to make the same allocations but should at least ensure that her efforts and investments in the police force meet the minimally acceptable international standards.

Eboh (2014) sees the federal government as abdicating her role as the 'genitor' of the Nigerian Police Force (NPF). He argues that the states (36 states) have being responsible for $70 \%$ of the NPF's funding while the Federal Government of Nigeria (FGN) took care of $30 \%$. He stressed that these figures in addition to the fact that the state governments bore a reasonable percentage of the platforms and other logistics elements, are grounds enough for them to be constitutionally allowed to establish, fund and operate police formations. Analysts contend that the FGN's full funding is only for salaries, pensions and infrastructure - which are in varying stages of disrepair, with unsanitary and decayed police barracks, police stations, police posts, rickety vehicles and clapped-out uniforms (Okonkwo 2014). Policemen trained or quartered in unfriendly and unhealthy environments are less likely to be friendly to the public. Indeed, the inability of the Federal Government to properly fund and equip the Nigeria Police Force to fight crimes has been given as the reason for the sustained high rate of insecurity in Nigeria (Eboh 2014). Evidently, the federal government is over burdened and decentralising police administration in the country to the state will ensure the proper oversight of their needs and activities. 


\title{
3.3 The Utilisation of policemen
}

Some critical issues in this regard include inappropriate and unethical deployment of the security personnel. Here, the capacity of the Police is further reduced due to the deployment of a good number of policemen to undertake "guard duties" and private security services for the rich and affluent in the society (Muazu, 2012). Perhaps, the greatest impediment to police effectiveness in Nigeria remains corruption (James, 2014). The limited funds meant for security and other developmental purposes are diverted by those responsible for their utilization. This creates an unending vicious cycle of poverty, deprivation, greed, exploitation, unemployment and general underdevelopment that culminates in weakening the capacity of government to provide social services, fund security ultimately undermining national security (Onwubiko, 2014).

A recall of policemen attached to politicians and non-force-men was made by the IGP in 2012 in order to keep tabs and enhance professionalism within the force (Fashola 2014). This was heeded though not in totality. The trend has slowly returned perhaps due to lapses within the system that prevented the full and proper enforcement of the directive. The solution to these impediments lie in a reform which would pave way for state police formations and give power to state governors over the police contingents in their states.

\subsection{Judicious Use of the Security Vote}

Another reason for advocating for state police policy is the effective utilisation of the security vote that state governors enjoy annually. Analysts believe that the security vote has been an avenue for the state governors to channel money into their private accounts. James (2014) quoted the claims of the Imo State governor on assumption of office that his predecessor was collecting N6.5 billion annually as security vote yet the crime rate was still high in the state. The same is true for the other states of the federation yet armed robbery; kidnapping, assassination, cultism and other social vices are on the increase. These are monies which if effectively channelled will cover the funding, training and equipment of state police formations.

\subsection{Decentralisation and the practice of true Federalism}

The Nigerian Police Force is not properly funded and supervised due to its centralized administrative structure and functions. The reclassification of the force into federal and state categories, as is obtainable in America and other developed nations may well boost the quality of its performance. Devolving the responsibility for police operations at the grassroots to the states asides giving attention to the welfare of the police, especially the rank and file, will checkmate the security challenges currently facing the nation. Okonkwo (2014) opined thus:

\begin{abstract}
"If it will take the creation of state police to address the security problems facing the country why can't we do that? Why should we continue to live with the present security challenges in the country when things can be better if we have state police? There are lots of lapses here and there because the governors are not really in charge of the security apparatus in the states. If there is a state police, the security challenge of every state will be the primary concern of the governors."
\end{abstract}

Segun (2014), also argued that if Nigeria is to operate a functional federal system of government it must not be done partially as all the basic tenets of federalism must be put in place. The Nigerian police formations can be modelled after the American type where each state has its own police. The arrangement is even more diffused and decentralised going from the community/city police, to the County, State and the FBI. Furthermore, Eboh (2014) revealed that the state police usually takes charge of highways and enforcement of state laws, while the cities have their separate police under the authority of a commissioner, who is an appointee of the mayor. Britain, a unitary system, has several local and regional police forces under separate and independent Chief Constables such as the Metropolitan Police, Greater Manchester Police, etc. The Metropolitan Police (under the Home Office), which covers an area of 15 miles radius, does not have jurisdiction over London, which has its own city police (Eboh 2014).

France also a unitary system operates a decentralised police force. While the gendarmerie is supervised by the armed forces, the "Surete Generale" is under the authority of provincial prefects who are the equivalent of governors. Paris, the capital, has its own police, called the Paris Prefecture (Segun, 2014). In these climes, crime rates have been reduced to the barest minimum. The secret of multi-forces policing of any nation-state is jurisdiction. Once, each service jurisdiction is clearly defined, a well policed community follows. This way, states with resources can give their police force the kind of training and facilities they can afford in order to secure the state against criminal elements. Even one, two or 
three states can pull resources jointly to establish one academy to train their local police officers as is the case with the police forces of the Indian states of Tamil Nadu and Maharashtra States.

Furthermore, the Constitution describes governors as the chief security officers in their states, yet they don't have authority over the police.

Okonkwo (2014) argued that the state governors can only be chief security officers when state police exists and they are effectively in-charge of security and the security apparatuses in their states. Ekweremadu (2014) declared ".... Nigeria is the only federal country in the whole world where we have a central police arrangement.... Security is a local issue and now what is bringing back the argument is the security challenge we have in this country now and unless we go back to a decentralised police arrangement we can never resolve the issue of our security in this country."

\subsection{Creating Employment Opportunities}

The establishment of state police will create employment opportunities for the army of unemployed school leavers in Nigeria, especially if the indigenes of the states become the targets of such recruitment exercises. Odeh and Okoye (2014) note that empowering the youths has always been used as a propaganda during political campaigns yet, no action has been put in place to mainstream the youths into all sectors of the economy. The societal cost of a large army of unemployed people, particularly young entrants in the labour market is unsettling. While mass demonstrations are not unusual in Nigeria, perhaps a much more threatening consequence of unemployment has been the resort to all forms of deviant and fraudulent behaviours, armed robbery, threats to lives and properties and the gross insecurity regularly witnessed across the country. Since youth unemployment is very severe in Nigeria, and is a huge challenge to national development, all available resources must be effectively mobilized to solve the problem. Table 2 shows the level of graduate unemployment rates in Nigeria from 2003 to 2011.

Table 2: Graduate unemployment rates 2003-2011

\begin{tabular}{|c|c|c|c|}
\hline YEAR & RURAL & URBAN & TOTAL \\
\hline 2003 & 8.3 & 17.3 & 25.6 \\
2004 & 12.8 & 25.2 & 38 \\
2005 & 13.3 & 19.0 & 32.3 \\
2006 & 13.4 & 18.8 & 32.2 \\
2007 & 13.4 & 18.7 & 32.1 \\
2008 & 21.7 & 15.8 & 37.5 \\
2009 & 19.8 & 19.2 & 39 \\
2010 & 20.7 & 22.8 & 43.5 \\
2011 & 25.6 & 17.1 & 42.7 \\
\hline
\end{tabular}

Source: The National Bureau of Statistics (NBS, 2011) in Odeh and Okoye(2014)

Table 2, reveals the critical extent of urban and rural graduate (youth) unemployment in Nigeria. Those in the rural areas can be trained and incorporated into the state police. This will not only serve the purpose of channelling the ever available youthful energy into effective state policing but will also reduce the rate of unemployment.

Table 3: Ratio of Security Agencies to the Population in Nigeria

\begin{tabular}{|c|c|c|c|}
\hline Security Agencies & Personnel Strength & National Population & Ratio \\
\hline Police & 371,000 & $160,000,000$ & $1: 431$ \\
\hline Army & 130,000 & $160,000,000$ & $1: 1,270$ \\
\hline Air Force & 15,000 & $160,000,000$ & $1: 11,000$ \\
\hline Navy & 18,000 & $160,000,000$ & $1: 9,167$ \\
\hline
\end{tabular}

(Source - Muazu, 2012)

State policing will improve the ratio of available policemen to the country's teeming population which based on table 3 is poor and grossly inadequate for handling both internal and external security challenges of today. 


\subsection{Effective Intelligence Gathering}

Muazu, (2012) asserted that policing and law enforcement are not only the maintenance of law and order, they include an array of activities in different situations with the predominant ones concerned with the preservation of social order. In many societies both developed and developing, several activities have evolved within the context of policing the political/democratic system, the protection of property and the latest which involves community policing. Community policing can only be done properly at the local level of the Nigerian society - all suffused within the ambit of intelligence activity. Most people believe that the Boko Haram insurgence is being prolonged because the police in its present form are inhibited by some factors that make victory difficult. Majority of the policemen in Borno state are non-indigenes who do not know the terrain and thus cannot be very effective for intelligence gathering without blowing their cover.

Egbosiuba (2013) sees a major problem with the Nigerian Police Force being that they are too removed from the people. Relationships between them and the local communities are virtually non-existent. Effective policing becomes more of a challenge when there is little trust between the police or law enforcement agents and local communities. Local inhabitants who know these criminals are unlikely to report them to the police when trust is lacking. The challenges posed by Boko Haram in the Northern parts of Nigeria, incessant violent crimes and the endemic corruption all over the country make it imperative that other alternatives to the status-quo be explored. In consensus with the foregone, the NBFNews (2014) asserted that most crimes are local in nature; hence, there is a need for local police formations in Nigeria. Although some crimes are indeed local, most major crimes, such as terrorism, trafficking in drugs and human persons, money laundering, robbery and burglary are national and international in character.

Pundits may canvass the argument that community policing should suffice at the lower levels of operation, however, the level of sophistication of weapons and incessant dare-devil attacks on innocent citizens necessitate a level of government involvement that goes beyond the level of the vigilante groups etc, due of the training and exposure that will be brought to bear (NBFNews 2014). Concomitantly, crime detection, prevention and citizen protection needs a broader knowledge which only state police can better provide especially when constituted of indigenes with a good knowledge of the community or terrain which is crucial for effectiveness

\section{Conclusion and Recommendations}

The study has exposed the urgent need to revisit the current skewed centralized policing arrangement. Daily, cogent reasons emerge that give verve to the importance of restructuring the existing system so that constitutional powers, resources and responsibilities of policing are devolved to the state levels. From many instances so far, the NPF has been powerless or at best has demurred in the handling of civil/religious crises in Nigeria. In the Niger Delta for example, the NPF could not cope with the intransigence of the militants, who practically took over some states, including the creeks, where they set up military camps, leading to the deployment of the Joint Task Force (JTF) to keep the peace. In the Jos Crisis, the NPF also failed and JTF had to come to the rescue. In the north east the NPF failed to stem the rising steam of Boko-Haram until the JTF intervened. Currently, many villages and communities pay monthly salaries or contributions to vigilante groups for communal security even while the current police formation exists (James, 2014). The answer to these failures is the establishment of state police, which will be better placed to undertake quick response to local crises.. The paper therefore proposes that a transitional scheme that will enable it materialize be put in place as a matter of urgency.

To effectively ensure the security of lives and properties the following recommendations are also proffered;

a. The Federal Government of Nigeria should establish the American-styled police structure and oversight offices in the 36 states to maintain Federal laws and complement the activities and functions of the state police. There should also be a Federal Criminal Investigation Branch (FCIB) established at the federal, state and local government levels. They are to be responsible for national/international criminal investigations. Their presence will ensure that ethnic sentiments do not come to play in the dispensation of justice, especially where non indigenes are concerned in the states.

b. To avoid the abuse of State Police Forces (SPF), the document backing the state police should provide for the establishment of ad-hoc committees at state and local government levels. These should be constituted of eminent citizens such as retired judges, religious leaders, respected opinion leaders, journalists and representatives of labour unions. Their duties should include the recommendation of police chiefs at the state level, as well as monitoring the general activities of the SPF. The state legislatures should also be given the oversight functions to ratify the committee's recommendations and regulate the security votes for the governors.

c. Structures of checks, balances and clear-cut disciplinary measures which insulate the state police officers 
from partisan politics and control by political office holders should be put in place to encourage efficiency and effectiveness.

d. A Police Regulatory Board (PRB) should be put in place to regulate and standardize police training so that a minimum national standard is maintained throughout the state police forces. The PRB should be established at the federal level to control all training schools.

e. In spite of the efforts to deal with corruption in the NPF by dismantling road blocks and dismissing police officers caught in corrupt acts, corruption is still the number one impediment to the effective performance of police functions in Nigeria and a cancer that has spread to every facet of the NPF. Corruption must be exposed and sanctioned appropriately and those who live above board should be rewarded in order to enhance the integrity of the force.

f. Agencies such as the EFCC, ICPC, FRSC, NAPTIP and NDLEA duplicate police functions. This is inimical to the effectiveness of NPF because they not only deprive the NPF of the already scarce material resources, but also deplete its pool of human resources. This should be discouraged and agencies performing similar functions merged for effectiveness.

g. The training curriculum of the police should be reviewed to include new and all encompassing vistas of policing such as crime scene management, forensics, human rights, police prosecution, professionalism based on ethics and values, election policing, information technology and public order policing and so on. Each area of training should be developed with specifics based on separate curricula manuals and levels of specialization or degrees of complexity.

h. Recruitment exercises should be transparent, rigorous and include psychological tests for profiling and determining the mental stability of recruits. Police officers must meet set standards of physical fitness, with regular fitness tests. To ensure this, every police station should have access to a fully equipped gymnasium.

i. All members of the police force should be given public relations training in order to be better equipped to communicate and relate with members of the public in ways that uphold human dignity while preserving police authority.

j. The unsanitary conditions that pervade the environments of police stations, unhealthy and untidy appearance of police officers, and the filthy and dilapidated police barracks have created a deep contempt for the police in the minds of the public. Senior officers within the stations should carry out regular inspections, with sanctions for dirty and unkempt premises and officers.

k. Police officers should be adequately remunerated and motivated to reduce the low self-esteem, aggression and corruption that erode the junior and some senior ranks.

\section{References}

Adamu, A. (1990), Redefining West African Security, a paper Presented at the Seminar on Global Changes and Challenges to SubRegional Maritime Security NIIA, Lagos, December.

Adebakin and Raimi (2012). National Security Challenges and Sustainable economic Development: Evidence from Nigeria. Journal of Studies in Social Sciences ISSN 2201-4624 Volume 1 (2012), Number 1, 1-30

Akuul T.(2011) The Role Of The Nigerian Police Force In Maintaining Peace And Security In Nigeria, Journal of Social Science and Public Policy, Volume 3, March 2011

Albert O.I. (2005) Terror as a Political Weapon: Reflections on the Bomb Explosions in Abacha's Nigeria. IFRA Ibadan, Special Research Issue 1, pp.37-56.

Babangida, M. A. (2012) The search for national security in Nigeria: Challenges and prospects. A paper presentation at ObafemiAwolowo Institute of Government and Public Policy, Agip Recital Hall, Muson-Lagos; Thursday, 27th September, 2012. Availableon http://www.nigerstate.gov.ng/articles/the-search-for-national-security-in-nigeria-challenges-and-prospects.html

Buzan, B. (1991) An introduction to Strategic Studies: Military technology and International relations, London: Macmillan

CBN (2012) Functional Classification of Federal Government Expenditure in Nigeria, Central Bank of Nigeria Annual Report Publication, Nigeria

Darmer, M.K.B., Baird, R. M. and Rosenbaum, S. E. (2004) Civil Liberties v. National Security In A Post 9/11 World, New York, Prometheus Books.

David B. (2006), The State of the Art in community policing: An International Perspective, http://www.aic.gov.au/en/publications. 18. Jack R. Greene, "Community Policing in America: Changing

Dyke, V.V. (1966) Security and Sovereignty in International Politics. New York:Appleton-Century-Crofts

Eboh (2014), Crime Prevention and Control in Nigeria: A Case for State Police, Nnamdi Ebo NewsBlog@ nnamdiebo.com , March 2, 2014

Eboh, M. and Obodoechina, R. (2012) loD flays public officers over security votes. The Vanguard, July 11. Available on http://www. 
vanguardngr.com/2012/07/iod-flays-public-officers-over-security-votes.

Egbosiuba M. (2013). Decentralization of Nigerian Police Force, Blog, All Things Nigeria.htm

Ehindero, S. (2012) Which Way Forward for the Nigeria police: Federal or State police,

Vanguard Newspaper February 2009

Ekweremadu I(2014) Policing and National Security in Nigeria: The Choices Before Us, Articles_ THISDAY LIVE.htm, 30th Mar 2013

Eme, O. I. (2009) Ethno-Religious Identities in Nigeria: Implications for Good Governance in Nigeria." A Paper submitted to the Editor-inChief of a Book Project on Islam and Governance in Nigeria.

Fashola (2014) Constitution Amendment: Fashola Canvasses State Police, Special Status for Lagos, Naija.com Blog 16th November, 2012

Information Nigeria (2014) Group Canvasses for State Police, Says Federal Police Has Failed, INFORMATION NIGERIA.htm, Thursday, 19 June 2014

James U (2014) Can State Police Solve Nigeria's Security Problem? Nigeria News World Magazine.htm, Thursday, 19th June, 2014

Krahmann E. (2003), Conceptualizing Security Governance. Journal of the Nordic International Studies Association Vol. 38 № 1.

McGrew Tony, (1988). Security and Order. in M. Smith; S Smith and B. White, British Foreign Policy: Tradition, Change and Transformation . London, Allen and Unwin Ltd.

McNamara, R. (1968), The Essence of Security, London: Harper and Row.

Muazu, B (2012), The Search For National Security In Nigeria: Challenges And Prospects www.nigerstate.gov.ng/../the-search-fornational-security-in-nigeria-cha.

NBFNews (2014) Which way forward for the Nigeria Police: Federal or State police? (2) Nigerian Latest News Papers News Online.htm, February 23, 2012

Nigerian Constitution (1999) Federal Republic of Nigeria (1999 Constitution). Abuja: Federal Government Printers.

Nweke, G.A. (1988) Some Critical Remarks on the National Security Question, Nigerian Journal of International Affairs. Vol. 12. pp. 1-7.

Nwolise, O.B.C (2006). National security and Sustainable Democracy in, Ojo, E. O. edited, Challenges of Sustainable Democracy in Nigeria . Nigeria, Ibadan: John Archer Publishers

Oche, O. (2001) Democratization and the Management of African Security" in Akindele, R. and Ate, .B (eds) in Nigerian Journal of International Affairs, vol.13, No.1, Lagos, NIIA.

Odeh and Okoye (2014) Poverty Reduction policy and Youth Unemployment in Nigeria; Journal of Public Policy and Administration Research 3(4): 92-103.

Okechukwu and Anyadike (2013), Security Challenges And Security Votes In Nigeria, 2008-2013, Kuwait Chapter of Arabian Journal of Business and Management Review Vol. 2, No.8; April. 2013

Okonkwo A.2014) The Nigeria Police Force: A Threat or a Pride? The Nigeria Police Force - Gamji www.gamji.com/article5000/ NEWS5214.htm

Oladesun, E. (2012). Can Jonathan restore security? The Nation news, Friday, July 20, P.43.

Umede, (2011). Nigeria: Analysing the Security Challenges of the Goodluck Jonathan Administration Canadian Social Science Vol. 7, No. 5,2011, pp. 90-102

Onwubiko P. (2014) National Security Summit: Can Nigeria have a different definition of federalism? RISE NETWORKS.htm, Blog , April 4, 2013

Otto, G. and Ukpere, W. I. (2012) National security and development in Nigeria. African Journal of Business Management Vol.6 (23), pp. $6765-6770$

Segun, A, (2014) A case against State Police in Nigeria Daily Independent News online, Thursday, June 19, 2014

Stan .F. (2004), The Security-Development Nexus: Conflict, Peace and Development in the 21st Century. New York: IPA Report.

Tinubu, K (1993). Future Police Statutory Function and Power in Policing Nigeria, Past, Present and"In Tekena, N.T. et al (ed) Lagos: Malthouse Press

Tunde-Awe, B. M. (2005) Proposing a curriculum for the Nigerian Police Force, llorin Journal of Education. Vol. 24, Pp. 23-30

Weber M. 1968) Economy and Society, USA: University of California Press 